\title{
TINGKAT KECEMASAN DAN MOTIVASI ATLET BASKET BANGKA BELITUNG SAAT MENJELANG PERTANDINGAN
}

\author{
Dzihan Khilmi Ayu Firdausi ${ }^{1}$,Nerri Lestari ${ }^{2}$, Karmila Sari $^{3}$, Peri Sagita ${ }^{4}$, Cici Cahyati ${ }^{5}$, Denis \\ Karianto ${ }^{6}$, Regi Prasetio ${ }^{7}$, Decky Irawan ${ }^{8}$ \\ Fakultas Keguruan dan Ilmu Pendidikan, Universitas Muhammadiyah Bangka Belitung, Bangka Belitung, \\ Indonesia \\ email: nerril16@gmail.com
}

\begin{abstract}
ABSTRAK
Penelitian ini bertujuan untuk mengetahui tingkat kecemasan dan motivasi atlet basket Bangka Belitung saat menjelang pertandingan. Penelitian ini adalah penelitian kuantitatif deskriptif. Alat ukur yang digunakan dalam penelitian ini adalah kuesioner. Responden dalam penelitian yaitu 30 orang atlet basket di wilayah Bangka Belitung. Responden mengisi kuesioner melalui google formulir yang terdiri dari 10 butir pernyataan yang disebarkan lewat whatsapp kepada atlet basket Bangka Belitung. Penelitian ini menggunakan metode survei dan dianalisis secara deskriptif kuantitatif. Berdasarkan hasil penelitian tingkat kecemasan atlet yaitu 30\% dan masuk dalam kategori rendah, sedangkan tingkat motivasi atlet yaitu $70 \%$ dan masuk dalam kategori tinggi.
\end{abstract}

Kata kunci: Kecemasan, Motivasi, Basket, Bangka Belitung

\begin{abstract}
This study aims to determine the level of anxiety and motivation of Bangka Belitung basketball athletes before the match. This research is descriptive quantitative research. The measuring instrument used in this study is a questionnaire. Respondents in the study were 30 basketball athletes in the Bangka Belitung region. Respondents filled out a questionnaire through a google form consisting of 10 statement items distributed via whatsapp to Bangka Belitung basketball athletes. This study used a survey method and analyzed descriptively quantitatively. Based on the results of the research, the athlete's anxiety level is $30 \%$ and is in the low category, the athlete's motivation level is $70 \%$ and is in the high category.
\end{abstract}

Key words : Anxiety, Motivation, Basketball, Bangka Belitung

Dipublikasikan Oleh :

UPT Publikasi dan Pengelolaan Jurnal

Universitas Islam Kalimantan Muhammad Arsyad Al-Banjari Banjarmasin 


\section{PENDAHULUAN}

Setiap orang pastinya pernah mengalami kecemasan atau bahkan ketakutan terhadap berbagai situasi seperti takut dimarahi, takut gagal, dan takut atau khawatir sebelum bertanding. Kecemasan dalam pertandingan ini akan menimbulkan tekanan emosi yang berlebihan yang tentu dapat mengganggu pelaksanaan pertandingan serta mempengaruhi penampilan atau prestasi seseorang. Kecemasan adalah perasaan yang dapat menimbulkan tekanan emosi yang dialami oleh siapa saja, kapan, dan di mana saja saat menghadapi suatu keadaan yang penting, misalnya menghadapi suatu pertandingan. Perasaan cemas muncul dalam diri atlet disebabkan oleh faktor intrinsik maupun ekstrinsik sehingga hal ini dapat mempengaruhi penampilan atlet saat bertanding. Gambaran asumsi seperti membayangkan lawan yang lebih kuat, tentang kondisi fisik yang tidak cukup baik, event yang sangat besar atau semua orang menaruh harapan yang berlebihan bisa mengakibatkan kecemasan yang berlebihan (Nindyowati \& Priyonoadi, 2016).

Kecemasan adalah reaksi dari rasa takut terhadap suatu situasi dan kondisi atau kesehatan mental yang membutuhkan pengobatan yang dimunculkan karena gejala psikologi akibat keadaan yang baru saja muncul. Gejala-gejala kecemasan ini biasanya ditandai dengan munculnya kekakuan, gemetar dan perasaan takut (Kumbara et al., 2019). Pada program pembinaan olahraga, sering dijumpai seorang atlet yang telah mempersiapkan diri dengan baik untuk menghadapi suatu pertandingan tiba-tiba mengalami gangguan pada pencernaan, sehingga atlet tidak bisa mengikuti pertandingan tersebut. Hal ini menujukkan adanya gejala kecemasan yang tentu saja perlu diatasi dengan serius, karena tidak menutup kemungkinan akan menghambat usaha atlet untuk dapat tampil secara optimal dan meraih prestasi yang ingin dicapai (Kusumajati, 2011)

Penampilan atlet dalam pertandingan sehingga mampu mencapai prestasi yang optimal merupakan perpaduan dari berbagai faktor, diantaranya yaitu faktor fisik, keterampilan motorik, teknik dan latihan. Disamping itu faktor psikologis seperti kepribadian, motivasi, percaya diri (The Confidence), juga merupakan faktor-faktor penting yang perlu diperhatikan oleh pelatih,pembina maupun guru pendidikan jasmani. Psikologi olahraga ini diterapkan untuk membantu membentuk atlet agar dapat memperlihatkan prestasi puncak, dan bagi atlet berbakat agar bakatnya bisa dikembangkan sebaik-baiknya tanpa hambatan dari faktor-faktor yang ada dalam kepribadiannya (Wismanadi, 2017).

Kecemasan dalam pertandingan akan memunculkan tekanan emosi yang berlebih, sehingga fokus atlet untuk menghadapi lawan akan berkurang. Hal ini dapat membuat kinerja dari atlet tersebut menurun, maka kecermatan juga akan menurun dan tentunya menyebabkan prestasi dari atlet tersebut ikut menurun. Karena pada saat bertanding, aspek yang sangat menentukan adalah mental atau psikologis atlet itu sendiri. Kondisi fisik, teknik, dan taktik sudah dipersiapkan jauh saat sebelum pertandingan, namun semua itu akan sia-sia jika atlet tidak dapat mengendalikan kecemasannya (Wismanadi, 2017).

Kecemasan umumnya muncul jika dihadapkan dengan sesuatu yang baru, seperti pertandingan awal atau menghadapi pertandingan yang besar, kecemasan biasanya terjadi karena reaksi dari kondisi psikologis dan perasaan yang terlihat pada diri individu tersebut saat menghadapi sesuatu. Kecemasan adalah rasa takut atau khawatir pada keadaan tertentu yang dirasa mengancam serta menyebabkan kegelisahan dan merasa selalu waspada terhadap sesuatu yang dirasa ancaman yang tidak jelas dan ketakutan bahwa sesuatu yang buruk akan terjadi (Dwi, 2022).

Sebagai makhluk sosial, manusia pasti berhubungan dengan orang lain. Hal tersebut memungkinkan seseorang mengalami masalah. Masalah yang dihadapi dapat terjadi karena berbagai sebab, seperti kurangnya penyesuaian diri, adanya pertentangan antara kebutuhan kita dengan kebutuhan orang lain, dan gagalnya dalam pemuasan kebutuhan. Jika situasi tersebut tidak diatasi dan tidak berjalan baik, maka muncullah kecemasan.

Setiap orang pasti pernah mengalami situasi digeluti rasa takut atau cemas dalam berbagai situasi. Takut dimarahi, takut salah dalam mengambil keputusan, takut gagal, tidak puas, takut kalah, dan sebagainya. Tidak menutup kemungkinan hal semacam ini terjadi pada atlet, apalagi saat menjelang pertandingan. Dalam menghadapi pertandingan sangat wajar jika seorang atlet menjadi tegang, bimbang, gelisah, khawatir, takut dan cemas, terutama kalau atlet tersebut menghadapi lawan yang seimbang atau bahkan lebih kuat dalam suatu pertandingan.

Perasaaan cemas dapat juga terjadi pada atlet pada saat menghadapi kondisi tertentu, misalnya dalam menghadapi kompetisi yang memakan waktu yang panjang dan ternyata atlet tersebut mengalami kekalahan terus-menerus selama ia bertanding. Seorang atlet wajar memiliki rasa khawatir akan kalah dalam menghadapi lawan, dan selalu dibayang-bayangi ketakutan. Apalagi jika atlet tersebut baru pertama kali ikut pertandingan. Oleh karena itu atlet harus dapat meningkatkan kewaspadaannya dalam mengadapi lawan. Atlet harus bertindak lebih berhati-hati, tidak gegabah dan waspada untuk mengantisipasi serangan lawan. Apabila atlet menghadapi kekhawatiran yang berlebihan, ia akan extra hati-hati dan waspada, takut berbuat salah, tidak berani membuat keputusan dan bersikap menunggu (Kusumajati, 2011).

Dipublikasikan Oleh :

UPT Publikasi dan Pengelolaan Jurnal

Universitas Islam Kalimantan Muhammad Arsyad Al-Banjari Banjarmasin 
Perasaan takut dan khawatir yang dirasakan oleh seseorang tentang suatu hal yang akan terjadi disebut dengan kecemasan. Umumnya kecemasan merupakan kondisi yang diartikan sebagai sebuah ancaman yang dirasakan oleh seseorang dan dapat mempengaruhi keberlangsungan hidup sesorang yang mengalaminya. Atlet yang diliputi perasaan takut akan kalah dalam bertanding, khawatir penampilannya tidak maksimal juga bsa disebut sebuah kecemasan yang dialami oleh atlet berkaitan dengan cabang olahraga yang ditekuninya, sehingga kecemasan yang muncul akibat dari kegiatan olahraga bisa disebut dengan kecemasan olahraga (Amaliyah \& Khoirunnisa, 2018).

Berikut gejala-gejala kecemasan atlet saat menjelang pertandingan yaitu munculnya kekakuan, gemetar, dan rasa takut. Berdasarkan hasil penelitian dari (Kumbara et al., 2018) menjelaskan bahwa penyebab munculnya kecemasan sebelum bertanding pada atlet adalah (1) kompetitif anxiety ditandai dengan gejala-gejala takut tidak sukses dan gagal dilapangan, (2) kognitif anxiety gejalanya adalah munculnya ekspektasi negatif serta takut dievaluasi dan (3) somatic anxiety gejalanya adalah gejala fisik misalnya kejang perut, berkeringat, dan jantung berdebar.

Gejala-gejala yang muncul dalam pertandingan misalnya rasa cemas, rasa khawatir, rasa takut, ketegangan, kebingungan, kurang atau hilang konsentrasi, dan rasa percaya diri yang menurun menyebabkan penampilan atlet menurun dalam suatu pertandingan. Ini merupakan salah satu faktor yang membuat kegagalan yang dialami oleh para atlet yaitu kurangnya pembinaan mental bagi atlet itu sendiri selama ia latihan (Putri et al., n.d.).

Motivasi adalah dorongan dalam diri atlet yang menyebabkan adanya keinginan atau hasrat untuk bisa mencapai sesuatu yang diimpikan (Soleh \& Hakim, 2019). Prestasi atlet merupakan hasil dari kombinasi antara latihan dan motivasi atlet, sehingga motivasi ini dipandang penting dalam mencapai tujuan yaitu atlet berprestasi maksimal. Terdapat dua jenis motivasi dalam olahraga yaitu motivasi intrinsik dan ekstrinsik. Motivasi intrinsik adalah dorongan yang kuat dari dalam yang menyebabkan seseorang itu berpartisipasi. Atlet yang mempunyai motivasi intrinsik biasanya mempunyai kepribadian yang matang, jujur, sportif, tekun, percaya diri, dan disiplin. Motivasi intrinsik inilah yang harus selalu ditumbuh kembangkan dalam diri individu, sayangnya motivasi ini sulit dipelajari. Sedang motivasi ekstrinsik merupakan dorongan berasal dari luar individu yang menyebabkan seseorang berpartisipasi dalam olahraga, contohnya dorongan dari pelatih, teman, orang tua, guru, kelompok, bangsa, hadiah, bonus uang, dsb (Effendi, 2016)

Motivasi adalah proses yang bermaksud untuk mendorong seseorang untuk berbuat atau tidak dalam berbagai situasi (Gunawan, 2019). Motivasi dalam olahraga dapat dibagi atas motivasi primer dan sekunder; dapat pula atas motivasi biologis dan sosial. Namun banyak ahli setuju membagikannya atas dua jenis, yaitu intrinsik dan ekstrinsik.(Muskanan, 2016). Dalam meraih prestasinya, seorang atlet dipengaruhi oleh banyak sekali faktor, salah satunya yaitu faktor psikologis yang didalamnya terdapat faktor motivasi (Kuspriyani \& Setyawati, 2014)

Motivasi erat kaitannya dengan pribadi dan dorongan dari dalam diri atlet untuk mencapai prestasi. Setiap atlet pastinya memiliki tingkat motivasi yang berbeda. Ada atlet yang memiliki dorongan yang kuat untuk mencapai prestasi setinggi-tingginya, ada juga yang tidak. Motivasi sesungguhnya merupakan suatu yang muncul secara alami pada diri seorang atlet (Clarasasti \& Jatmika, 2017)

Motivasi juga dapat diartikan sebagai serangkaian usaha yang dapat dilakukan untuk menyediakan kondisi-kondisi tertentu, sehingga orang yang awalnya tidak ingin atau tidak mau melakukan sesuatu, menjadi ingin dan mau melakukan sesuatu. Dan jika ia tidak suka, maka orang tersebut akan berusaha semaksimal mungkin untuk menghilangkan perasaan tidak suka itu.

Setiap manusia pasti membutuhkan motivasi dalam hidupnya, meskipun jenis dan tingkatanya berbeda. Jika tidak adanya motivasi tentu manusia tidak akan dapat berbuat apa-apa, karena motivasilah yang menggerakan tingkah laku manusia. Motivasi yang ada pada diri manusia salah satunya adalah adanya dorongan untuk sukses atau berhasil. Dorongan tersebut seharusnya ada pada diri tiap atlet, untuk mencapai prestasi yang hendak dicapai pada suatu cabang olahraga (Wattimena, 2015)

Bola basket merupakan salah satu cabang olahraga yang cukup banyak digemari oleh masyarakat luas, dari anak-anak sampai dewasa baik laki-laki maupun perempuan. Bola basket merupakan salah satu cabang olahraga yang masuk dalam kelompok bola besar, dalam permainannya terdiri dari kelompok yang beranggotakan 5 orang. Permainan ini menggunakan bola pantul karet di lapangan, poin dalam permainan ini bisa didapatkan dengan memasukkan bola pada keranjang lawan. Berbagai macam persiapan dan latihan dilakukan demi mendapatkan hasil terbaik dengan tujuan untuk mengalahkan lawan yang memiliki kemampuan lebih dari atlet tersebut. Macam- macam bayangan dan perasaan khawatir dari atlet mengenai pertandingan yang akan dijalaninya, khawatir kalah dalam permainan, takut akan penampilan yang tidak maksimal bahkan

Dipublikasikan Oleh :

UPT Publikasi dan Pengelolaan Jurnal

Universitas Islam Kalimantan Muhammad Arsyad Al-Banjari Banjarmasin 
kemungkinan cidera yang bisa dialaminya dan kemungkinan-kemungkinan buruk lainnya yang dinilai sebagai ancaman dalam cabang olahraga yang ditekuni sebagai seorang atlet (Amaliyah \& Khoirunnisa, 2018)

Permainan bola basket memperlihatkan keterampilan gerak dasar seperti passing, dribbling, dan shooting. Pemain melakukan gerak yang sangat terampil dan gesit dalam melakukan permainan sehingga bila dilihat menjadi sangat menarik dalam suatu permainan bola basket (Febrianta \& Sukoco, 2013). Bola basket termasuk salah satu cabang olahraga permainan yang dimainkan oleh dua tim yang saling berlawanan, setiap tim terdiri dari 12 pemain, yang masing-masing tim memainkan 5 orang pemain pertama di lapangan. Setiap tim sebisa mungkin harus membuat skor dengan cara memasukkan bola ke keranjang lawan sebanyak-banyaknya dan harus mencegah lawan untuk memasukkan bola (Sitepu, 2016).

Perkembangan olahraga bola basket di Indonesia sudah berkembang cukup pesat. Hal ini bisa dilihat dari banyaknya masyarakat yang mengikuti latihan pada klub bola basket. Penggemar bola basket tidak hanya usia-usia tertentu saja, melainkan bisa dilakukan oleh berbagai jenjang usia, anak-anak, remaja, dewasa hingga orang tua. Permainan bola basket mempunyai teknik dasar yang harus dikuasai oleh peserta didik yaitu passing, dribbling dan shooting (Prakoso \& Sugiyanto, 2017).

Mencetak poin sebanyak-banyaknya ke ring lawan adalah tujuan untuk mendapatkan kemenangan tim. Melakukan teknik permainan bola basket yang baik dan benar akan mendukung kemampuan pemain untuk dapat mencetak poin (Mertayasa et al., 2016).

\section{METODE}

Penelitian jenis ini merupakan kajian kuantitatif deskriptif untuk mengetahui tingkat kecemasan dan motivasi atlet basket Bangka Belitung saat menjelang pertandingan. Variabel dalam penelitian ini adalah tingkat kecemasan dan motivasi atlet basket Bangka Belitung saat menjelang pertandingan. Responden dalam penelitian ini adalah 30 orang atlet basket Bangka Belitung. Teknik yang digunakan dalam penelitian ini adalah Simple Random Sampling. Data dianalisis menggunakan statistik deskriptif dengan bantuan komputerisasi.

Prosedur Penelitian

Agar proses penelitian pada metode penelitian deskriptif kuantitatif lebih terarah, sehingga di buat desain penelitian, untuk desain penelitian yang diterapkan dalam penelitian ini yaitu menggunakan penilaian data angket. Dimana setiap atlet mengisi 10 butir pernyataan yang disebarkan lewat whatsapp. Untuk prosedur ini dilakukan sebanyak satu kali dan wajib mengisi semua butir pernyataan yang berada dalam angket.

Kemudian pengolahan hasil penelitian ditentukan dengan kriteria konversi, menurut Arikunto (2006), kemudian data tersebut diinterpretasikan kedalam lima tingkatan yaitu :

Tabel.1 Kategori Kecemasan dan Motivasi

\begin{tabular}{lll}
\hline No & Interval & Kategori \\
\hline 1. & $81 \%-100 \%$ & Sangat tinggi \\
2. & $61 \%-80 \%$ & Tinggi \\
3. & $41 \%-60 \%$ & Sedang \\
4. & $21 \%-40 \%$ & Rendah \\
5. & $0 \%-20 \%$ & Sangat rendah \\
\hline
\end{tabular}

(Diadaptasi dari Arikunto, 2006)

Instrumen Penelitian

Instrumen penelitian yang digunakan dalam penelitian ini berupa angket yang terdiri dari 10 butir pernyataan yang bertujuan mengungkapkan tingkat kecemasan dan motivasi atlet basket Bangka Belitung saat menjelang pertandingan. Angket yang digunakan berupa angket tertutup. Berikut 10 butir pernyataan tersebut.

Tabel.2 Butir Pernyataan Angket

\begin{tabular}{ll}
\hline No & Pernyataan \\
\hline 1 & Saya tidak takut menghadapi event selanjutnya walaupun pada event sebelumnya saya gagal \\
2 & Saya merasa takut dan khawatir bila tidak bisa memenangkan pertandingan \\
3 & Jika saya mendapat teguran dari pelatih dan teman satu teman saat melakukan kesalahan maka \\
& $\begin{array}{l}\text { penampilan saya akan menurun } \\
4\end{array}$ \\
& $\begin{array}{l}\text { Saya merasa khawatir menjelang pertandingan karena membayangkan beratnya pertandingan yang akan } \\
5\end{array}$ \\
6 & Saya merasa lebih bersemagar jika mendapatkan reward/hadiah \\
7 & Saya merasa bersemangat jika dipuji \\
8 & Saya diliputi keraguan diri dalam mengambil keputusan \\
\hline
\end{tabular}

Dipublikasikan Oleh :

UPT Publikasi dan Pengelolaan Jurnal

Universitas Islam Kalimantan Muhammad Arsyad Al-Banjari Banjarmasin 
$9 \quad$ Saya mudah terganggu dan kehilangan konsentrasi pada setiap pertandingan

10 Saya merasa tegang setiap mengawali pertandingan

\section{HASIL DAN PEMBAHASAN}

Penyebaran angket penelitian ini dilaksanakan dalam kurun waktu 7 hari. Hasil penyebarannya mengumpulkan sebanyak 30 responden. Responden dalam penelitian ini yaitu atlet basket Bangka Belitung.

Tabel.3 Butir Pernyataan angket

\begin{tabular}{|c|c|c|}
\hline Data angket & & $\%$ \\
\hline \multirow[t]{2}{*}{ Butir 1} & $\mathrm{Ya}$ & 90 \\
\hline & Tidak & 10 \\
\hline \multirow{2}{*}{ Butir 2} & $\mathrm{Ya}$ & 40 \\
\hline & Tidak & 60 \\
\hline \multirow[t]{2}{*}{ Butir 3} & $\mathrm{Ya}$ & 16,7 \\
\hline & Tidak & 83,3 \\
\hline \multirow[t]{2}{*}{ Butir 4} & $\mathrm{Ya}$ & 40 \\
\hline & Tidak & 60 \\
\hline \multirow[t]{2}{*}{ Butir 5} & $\mathrm{Ya}$ & 80 \\
\hline & Tidak & 20 \\
\hline \multirow{2}{*}{ Butir 6} & $\mathrm{Ya}$ & 60 \\
\hline & Tidak & 40 \\
\hline \multirow[t]{2}{*}{ Butir 7} & $\mathrm{Ya}$ & 70 \\
\hline & Tidak & 30 \\
\hline \multirow[t]{2}{*}{ Butir 8} & $\mathrm{Ya}$ & 40 \\
\hline & Tidak & 60 \\
\hline \multirow[t]{2}{*}{ Butir 9} & $\mathrm{Ya}$ & 26,7 \\
\hline & Tidak & 73,3 \\
\hline \multirow[t]{2}{*}{ Butir 10} & $\mathrm{Ya}$ & 36,7 \\
\hline & Tidak & 63,3 \\
\hline
\end{tabular}

Berdasarkan hasil penelitian yang kami lakukan tingkat kecemasan dan motivasi atlet basket Bangka Belitung saat menjelang pertandingan yaitu sebanyak $90 \%$ atlet merasa tidak takut menghadapi event selanjutnya walaupun event sebelumnya gagal dan sebanyak $10 \%$ atlet merasa takut menghadapi event selanjutnya setelah gagal di event sebelumnya. Sebanyak $40 \%$ atlet merasa takut dan khawatir bila tidak bisa memenangkan pertandingan dan sebanyak $60 \%$ atlet merasa tidak takut dan khawatir bila tidak bisa memenangkan pertandingan. Sebanyak $16,7 \%$ atlet merasa penampilannya menurun jika mendapat teguran dari pelatih dan teman satu tim saat melakukan kesalahan dan sebannyak 83,3 atlet merasa penampilannya tidak menurun jika mendapat teguran dari pelatih dan teman satu tim saat melakukan kesalahan. Sebanyak $40 \%$ atlet merasa khawatir menjelang pertandingan karena membayangkan beratnya pertandingan yang akan dihadapi dan sebanyak $60 \%$ atlet merasa tidak khawatir menjelang pertandingan karena membayangkan beratnya pertandingan yang akan dihadapi. Sebanyak $80 \%$ atlit merasa lebih bersemangat jika mendapat reward/hadiah dan sebanyak $20 \%$ merasa tidak bersemangat walaupun mendapat reward/hadiah. Sebanyak $60 \%$ atlit merasa bersemangat saat mendapat pujian dan sebanyak $40 \%$ atlit merasa tidak bersemangat walaupun mendapat pujian. Sebanyak $70 \%$ atlit merasa lebih bersemangat jika mendapatkan banyak perhatian dan sebanyak $30 \%$ atlit merasa tidak bersemangat jika mendapatkan banyak perhatian. Sebanyak $40 \%$ atlit merasa ragu dalam mengambil keputusan dan sebanyak 60\% atlit tidak merasa ragu dalam mengambil keputusan. Sebanyak 26,7\% atlit mudah terganggu dan kehilangan konsentrasi pada setiap pertandingan dan sebanyak $73,3 \%$ tidak terganggu dan tetap bisa berkonsentrasi pada setiap pertandingan. Sebanyak $36,7 \%$ atlit merasa tegang setiap mengawali pertandingan dan sebanyak $63,3 \%$ atlit merasa tidak tegang setiap mengawali pertandingan.

\section{PENUTUP}

Berdasarkan hasil penelitian Tingkat Kecemasan dan Motivasi Atlet Basket Bangka Belitung Saat Menjelang Pertandingan dapat disimpulkan bahwa tingkat kecemasan atlet yaitu 30\% masuk dalam kategori rendah dan motivasi atlet yaitu $70 \%$ masuk dalam kategori tinggi.

\section{REFERENSI}

Dipublikasikan Oleh :

UPT Publikasi dan Pengelolaan Jurnal

Universitas Islam Kalimantan Muhammad Arsyad Al-Banjari Banjarmasin 
Amaliyah, A. K., \& Khoirunnisa, R. N. (2018). Pertandingan Pada Atlet Bola Basket Di Unit Kegiatan Mahasiswa Universitas Negeri Surabaya. Jurnal Penelitian Psikologi, 5(2), 5.

Clarasasti, E. I., \& Jatmika, D. (2017). Pengaruh Kecemasan Berolahraga terhadap Motivasi Berprestasi Atlet Bulutangkis Remaja di Klub J Jakarta. Humanitas (Jurnal Psikologi), 1(2), 121. https://doi.org/10.28932/humanitas.v1i2.421

Dwi, K. (2022). Pengaruh Efikasi Diri dan Motivasi Berprestasi terhadap Kecemasan Menghadapi Pertandingan Sepak Bola pada Pemain Bola SSB Bintang Ragunan. 6(2), 1-7.

Effendi, H. (2016). Peranan psikologi olahraga dalam meningkatkan prestasi atlet. Nusantara (Jurnal Ilmu Pengetahuan Sosial), 1(1), 22-30.

Febrianta, Y., \& Sukoco, P. (2013). Upaya Peningkatan Pembelajaran Permainan Bolabasket Melalui Metode Pendekatan Taktik Siswa Smpn 2 Pandak Bantul. Jurnal Keolahragaan, 1(2), 186-196. https://doi.org/10.21831/jk.v1i2.2574

Gunawan, E. (2019). Motivasi Bermain Bola Basket Siswa Sma Negeri 12 Makassar. Jp.Jok (Jurnal Pendidikan Jasmani, Olahraga Dan Kesehatan), 2(2), 14-23. https://doi.org/10.33503/jpjok.v2i2.447

Kumbara, H., Metra, Y., \& Ilham, Z. (2018). Analisis Tingkat Kecemasan (Anxiety) Dalam Menghadapi Pertandingan Atlet Sepak Bola Kabupaten Banyuasin Pada Porprov 2017 Hengki Kumbara 1 Yogi Metra 2 Zulpikar Ilham 3. Jurnal Ilmu Keolahragaan, 17(2), 28-35.

Kumbara, H., Metra, Y., \& Ilham, Z. (2019). Analisis Tingkat Kecemasan (Anxiety) Dalam Menghadapi Pertandingan Atlet Sepak Bola Kabupaten Banyuasin Pada Porprov 2017. Jurnal Ilmu Keolahragaan, 17(2), 28. https://doi.org/10.24114/jik.v17i2.12299

Kuspriyani, D. S., \& Setyawati, H. (2014). Survei Motivasi Prestasi Atlet Klub Bulutungkis Pendowo Semarang Tahun 2014. Journal of Physical Education Health and Sport, 1(2), 108-114.

Kusumajati, D. A. (2011). Hubungan antara Kecemasan Menghadapi Pertandingan dengan Motivasi Berprestasi pada Atlet Anggar di DKI Jakarta. Humaniora, 2(1), 58. https://doi.org/10.21512/humaniora.v2i1.2948

Mertayasa, K., Rahayu, S., \& Soenyoto, T. (2016). Metode latihan plyometrics dan kelentukan untuk meningkatkan power otot tungkai dan hasil lay up shoot bola basket. Journal of Physical Education and Sports, 5(1), 24-31.

Muskanan, K. (2016). Analisis Motivasi Berprestasi Atlet Pusat Pendidikan Dan Latihan Olahraga Pelajar (PPLP) Provinsi Nusa Tenggara Timur. Jurnal Psikologi, 5(1), 187-192. https://ojs.uma.ac.id/indexphp/analiti/article/view/2294\%0Ahttp://ejournal.uin-

suka.ac.id/tarbiyah/index.php/goldenage/article/download/1929/1408/\%0Ahttps://semnas.unikama.ac.id/lp pm/prosiding/2017/2.PANGAN \& TERNAK/Dyah_Nurul_A_Penelitian_Pangan_Ternak.

Nindyowati, M. H., \& Priyonoadi, B. (2016). Tingkat kecemasan atlet aeromodelling kelas free flight setelah mengalami cedera bahu menjelang pertandingan. 69-84.

Prakoso, G. P. W., \& Sugiyanto, F. (2017). Pengaruh metode latihan dan daya tahan otot tungkai terhadap hasil peningkatan kapasitas VO2Max pemain bola basket. Jurnal Keolahragaan, 5(2), 151. https://doi.org/10.21831/jk.v5i2.10177

Putri, R., Sari, P., \& Karate, A. (n.d.). Pertandingan Mahasiswa S-1 Pendidikan Kepelatihan Olahraga, Fakultas Ilmu Keolahragaan Universitas Negeri Rini Ismalasari, S . Pd., M. Kes . Dosen S-1 Pendidikan Kepelatihan Olahraga, Fakultas Ilmu Keolahragaan Universitas Negeri Surabaya rini.ismala.

Sitepu, D. I. (2016). Hubungan Keterampilan Teknik Dasar Bola Basket Dan Motivasi Berprestasi Terhadap Minat Mahasiswa Menjadi Wasit Cabang Olahraga Bola Basket Di Fik Unimed. Jurnal Ilmu Keolahragaan Vol., 15(1), 77-84.

Soleh, B., \& Hakim, A. A. (2019). Analisis Tingkat Kecemasan, Kepercayaan Diri Dan Motivasi Atlet Futsal Childroom Analisis Tingkat Kecemasan, Kepercayaan Diri Dan Motivasi Atlet Futsal CHILDROOM Di Bangkalan Saat Menjelang Pertandingan.

Wattimena, F. Y. (2015). Hubungan motivasi berprestasi dan kecemasan terhadap prestasi panahan ronde recurve pada atlet panahan di Indonesia. Motion: Jurnal Riset Physical Education, 6(1), 109-122.

Wismanadi, H. (2017). Hubungan Tingkat Kecemasan Dengan Performa Atlet Tim Bolabasket Putra Kota Surabaya Dalam Persiapan Pekan Olahraga Provinsi Iv Di Kota Madiun. JOSSAE : Journal of Sport Science and Education, 2(1), 25. https://doi.org/10.26740/jossae.v2n1.p25-26

Dipublikasikan Oleh :

UPT Publikasi dan Pengelolaan Jurnal

Universitas Islam Kalimantan Muhammad Arsyad Al-Banjari Banjarmasin 
Dipublikasikan Oleh :

UPT Publikasi dan Pengelolaan Jurnal

Universitas Islam Kalimantan Muhammad Arsyad Al-Banjari Banjarmasin 